\title{
Environmental exposure of pharmaceuticals and musk fragrances in the Somes River before and after upgrading the municipal wastewater treatment plant Cluj-Napoca, Romania
}

\author{
Zaharie Moldovan • Romeo Chira • Alfredo C. Alder
}

Received: 25 April 2008 / Accepted: 14 August 2008 /Published online: 30 October 2008

(C) Springer-Verlag 2008

\begin{abstract}
Background, aim, and scope Pharmaceutically active substances are a class of emerging contaminants, which has led to increasing concern about potential environmental risks. After excretion, substantial amounts of unchanged pharmaceuticals and their metabolites are discharged into domestic wastewaters. The absence of data on the environmental exposure in Eastern Europe is significant, since use patterns and volumes differ from country to country. In Romania, the majority of wastewater, from highly populated cities and industrial complex zones, is still discharged into surface waters without proper treatment or after inefficient treatment. In respect to this, it is important to determine the environmental occurrence and behavior of pharmaceuticals and personal care products (PPCPs) in wastewaters and surface waters. The objective of the present study was to
\end{abstract}

Responsible editor: Walter Giger

ESPR Special Issue - ESTROM

Z. Moldovan

Department of Mass Spectrometry, National Institute of Research and Development for Isotopic and Molecular Technology,

INCDTIM,

Str. Donath 71-103,

400293 Cluj-Napoca, Romania

R. Chira

Somes Water Company, Water and Sewerage Company Cluj, Bulevardul 21 Decembrie 1989 nr. 79,

400604 Cluj-Napoca, Romania

\section{A. C. Alder $(\bowtie)$}

Department of Environmental Chemistry,

Swiss Federal Institute of Aquatic Science and Technology,

Eawag,

Ueberlandstrasse 133,

CH-8600 Dübendorf, Switzerland

e-mail: alfredo.alder@eawag.ch investigate the occurrence of selected PPCPs during the transport in the Somes River by mass flow analysis before and after upgrading a municipal wastewater treatment plant (WWTP) in Cluj-Napoca, which serves 350,000 inhabitants and is the largest plant discharging into the Somes River. The concentrations of PPCPs at Cluj-Napoca can be correlated with the high population and a high number of hospitals located in the catchment area leading to higher mass flows. The results of this study are expected to provide information, with respect to the Romanian conditions, for environmental scientists, WWTP operators, and legal authorities. The data should support the improvement of existing WWTPs and implementation of new ones where necessary and, therefore, minimize the input of contaminants into ambient waters.

Materials and methods The PPCPs were selected on the basis of consumption at the regional scale, reported aquatic toxicity, and the suitability of the gas chromatography/mass spectrometry (GC/MS) method for the determination of the compounds at trace levels. The studied PPCPs, caffeine (stimulant), carbamazepine (antiepileptic), pentoxifylline (anticoagulant), cyclophosphamide (cytostatic), ibuprofen (analgesic), and galaxolide (musk fragrance), were determined in samples of the Somes River. The analytes were enriched by solid-phase extraction and subsequently determined by GC/MS. Caffeine, pentoxifylline, and galaxolide were determined underivatized, whereas the acidic pharmaceuticals carbamazepine, cyclophosphamide, and ibuprofen were determined after derivatization with $\mathrm{N}$-methyl- $\mathrm{N}$ (trimethylsilyl)-trifluoroacetamide.

Results and discussion The concentrations in the Somes River varied from below $10 \mathrm{ng} / \mathrm{L}$ up to $10 \mu \mathrm{g} / \mathrm{L}$. A substantial decrease of the exposure in the Somes River could be observed due to the upgrade of the municipal WWTP in Cluj-Napoca. The loads in the river stretch between Cluj-Napoca and Dej (Somes Mic) varied strongly: 
caffeine (400-2,000 g/day), carbamazepine (78-213 g/day), galaxolide (140-684 g/day), ibuprofen (84-108 g/day). After the upgrade of the WWTP Cluj-Napoca, the concentrations in the Somes of caffeine, pentoxifylline, cyclophosphamide, galaxolide, and tonalide were significantly reduced (over $75 \%$ ). One might be cautious comparing both studies because the relative efficiency of the WWTP's removal of PPCP was not evaluated. However, the significantly lower concentrations of most compounds after the upgrade of the WWTP Cluj-Napoca allow one to infer that the technical measures at the source substantially reduced inputs of contaminants to the receiving river. Dej loads of the poorly biodegradable substance carbamazepine increased by a factor of 2-3 as a result of wastewater discharges into the river. The disproportionate increase in caffeine loads by a factor of 4 below Cluj-Napoca indicates inputs of untreated wastewater from the Somes Mare due to the discharge of untreated wastewater derived from Bistrita, Nasaud, and Beclean (115,000 inhabitants).

Conclusions The relative contribution of treated and untreated wastewater in surface water might be assessed by measuring chemical markers. Recalcitrant pharmaceuticals like carbamazepine are suitable as chemical markers for estimating the relative contribution of wastewater in surface water. The easily degradable caffeine might be a good indicator for raw sewage and hardly treated wastewaters. Recommendations and perspectives Municipal WWTPs have the potential of a significant contribution in reducing the load of contaminants to ambient waters. The efficiency of the wastewater treatment in Cluj-Napoca improved considerably after the upgrade of the WWTP. Therefore, it is crucial that several WWTPs must be implemented or improved in the Somes Valley Watershed in order to reduce the discharge of contaminants in the Somes River from these point sources.

Keywords Cluj-Napoca · ESTROM · Mass flows · Musk fragrances $\cdot$ Personal care products (PPCP) .

Pharmaceuticals · Somes River - Wastewater treatment plant

\section{Background, aim, and scope}

Pharmaceutically active substances are a class of new, socalled emerging contaminants, which has led to increasing concern about potential environmental risks. After excretion, substantial amounts of unchanged pharmaceuticals and their metabolites are discharged into domestic wastewaters. If they are not removed during wastewater treatment, these substances will be discharged into ambient waters. Therefore, at least in highly developed countries where more than $90 \%$ of the dry weather wastewater flow is treated in municipal wastewater treatment plants
(WWTPs), the sewer system represents the major point source of pharmaceuticals and personal care products (PPCPs). Additionally, direct inputs into ambient waters are also possible through storm water overflow and leaks in the sewer system. Discharge of the effluents from WWTPs into the receiving waters results in a further dilution of the pharmacological active substances which occur at concentrations up to the high nanograms per liter range in contaminated surface water.

Over the last 10 years, the occurrence of PPCPs and natural estrogens in wastewater and surface water has been widely reported and extensively reviewed (e.g., Halling-Sorensen et al. 1998; Daughton and Ternes 1999; Heberer 2002; Jones et al. 2005; Alder et al. 2006; Lishman et al. 2006; Khetan and Collins 2007). Most of the studies showing the ubiquitous occurrence of PPCPs in the environment have been conducted in Western Europe and in North America, but very little is known about the situation in Eastern Europe. Environmental concentrations of PPCPs in North America may be different from Europe as a consequence of differing PPCP use patterns, water consumption, and operation conditions of municipal WWTPs. Sorption onto particles and biotransformation are the most significant processes determining the fate of PPCPs in municipal WWTP. The elimination rate of PPCPs is dependent of the physicochemical properties of the substance, on the treatment process applied, and on further factors, like the age of the activated sludge (solid retention time [SRT]), the hydraulic retention time (HRT), temperature of the wastewater, the microbial population, etc. SRT is a major factor influencing microbial transformation and maximum transformation was determined at an SRT >10-12 days for several PPCPs (Ternes et al. 2004; Joss et al. 2005). Once pharmaceuticals reach surface waters, they can be transformed mainly via biodegradation and photodegradation or they can sorb onto the suspended particles in the water. The concentrations in surface waters are very much dependent on the contribution of the wastewater flow to the receiving water flow and, therefore, of the dilution of the wastewater that occurs.

Data regarding the WWTP efficiency in Romania are not available. The absence of data for Eastern Europe is significant since the technology used and the WWTP efficiency differ from region to region. Generally, the WWTPs consist of a primary and a secondary treatment (grit, primary settler, and activated sludge treatment with secondary clarifier), although wastewaters are often discharged into surface waters without proper treatment.

The objective of our study was (1) to obtain systematic and comprehensive, analytically measured data on the occurrence and environmental behavior of PPCPs in surface water in the Somes Valley Watershed and (2) to evaluate the contribution of WWTP effluents before and after upgrading the municipal WWTP in Cluj-Napoca in the year 2003. The 
concentrations of PPCPs at Cluj-Napoca can be correlated with the high population and a high number of hospitals located in the catchment area leading to higher mass flows. The presented results and discussion are based on two earlier performed studies (Moldovan 2006; Moldovan et al. 2007). The pharmaceuticals and musk fragrances were selected on the basis of consumption at the regional scale, reported aquatic toxicity, and the suitability of the gas chromatography/mass spectrometry (GC/MS) method for the determination of the compounds at trace levels. The results of this study are expected to provide information for environmental scientists, WWTP operators, and legal authorities with respect to the Romanian circumstances. The data should support the improvement of existing WWTPs and implementation of new ones where necessary and, therefore, minimize the discharge of contaminants into ambient waters.

\section{Materials and methods}

\subsection{WWTP Cluj-Napoca}

The WWTP Cluj-Napoca is the largest WWTP in Transylvania, Romania and serves a residential population of around of 350,000 inhabitants. The average raw inflow was $86,000 \mathrm{~m}^{3} /$ day $\left(2 \mathrm{~m}^{3} / \mathrm{s}\right)$ during dry weather conditions.

After an upgrade in the year 2003, the WWTP was operated with a solid retention time of approximately 12 days. Primary treatment consists of a screen, grit removal, and a primary clarifier. The primary effluent is transferred into the activated sludge reactor and, subsequently, to the secondary clarifier. The combined hydraulic residence time in the primary clarifier, the aerobic reactor, and the secondary clarifier was approximately $24 \mathrm{~h}$. The secondary effluent is discharged into the Somes River. Before the upgrade, the aerobic treatment was one third of the present size, the total hydraulic residence time was $12-14 \mathrm{~h}$, and the solid retention time was approximately $2-4$ days. The average chemical oxygen demand (COD measured as BOD5) was $11 \mathrm{mg} / \mathrm{L}$ before the upgrade (2001) and $5.5 \mathrm{mg} / \mathrm{L}$ after the upgrade (2006).

\subsection{Description of the sampling site and sampling collection}

The Somes River Watershed is populated by $1,800,000$ inhabitants in the northwest of Romania. The Somes Mic originates south of Cluj-Napoca and merges at Dej with the Somes Mare to the Somes which flows into the Tiza in Hungary and later into the Danube. The Somes receives a variety of organic wastes from urban areas, factories, and individual households as well as treated and nearly untreated wastewater effluents from several municipal
WWTPs. The most important WWTPs in the Somes Mic are Cluj-Napoca, Gherla, and Dej.

The map of Somes River catchment and collection sites is shown in Fig. 1. The samples were taken at three sites along the $60-\mathrm{km}$ river stretch between Cluj-Napoca and Dej: site 1, downstream of Cluj-Napoca $(350,000$ inhabitants); site 2, downstream of Gherla (30,000 inhabitants); and site 3, upstream of Dej, after confluence of Somesul Mic $\left(20 \mathrm{~m}^{3} / \mathrm{s}\right)$ with Somesul Mare $\left(40 \mathrm{~m}^{3} / \mathrm{s}\right)$. The watershed of Somesul Mare before merging with the Somesul Mic is inhabited by approximately 115,000 residents.

Two sampling campaigns were conducted: the first river sampling occurred in April 2001 before the upgrade of the WWTP Cluj-Napoca and the second occurred in September 2006 after the upgrade. Grab samples were collected at the three sites, at least $1 \mathrm{~km}$ downstream of WWTPs effluents and the tributary Somes Mare. The river water samples were taken from $0.5 \mathrm{~m}$ under the surface. To have complete mixing between WWTP effluent and tributaries at the sampling location, samples were taken over the whole width (on a bridge) and combined to one sample. Grab samples of WWTP effluents were collected at the same time. The average flow of the river does not fluctuate very much, with a maximum flow during spring time demonstrating a $20 \%$ higher flow than in winter. The flow and the temperature of the Somes during both campaigns were comparable.

\subsection{Chemical analyses}

The detailed analytical method has been published elsewhere (Moldovan 2006; Moldovan et al. 2007). Briefly,

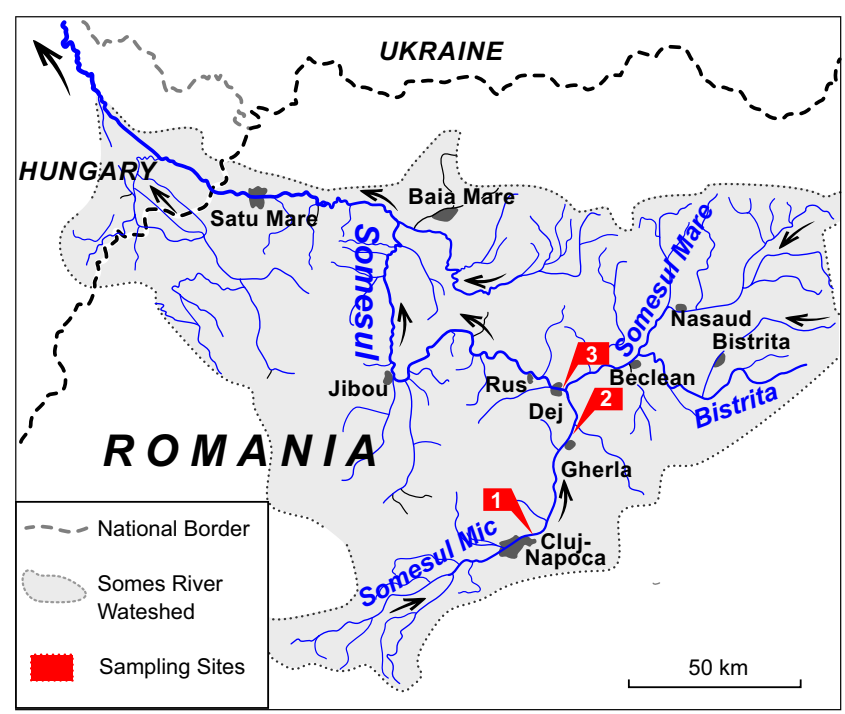

Fig. 1 Map of the Somes River catchment indicating the sampling sites $1-3$ in the Somes River 
river water samples $(500 \mathrm{~mL})$ were enriched by solid-phase extraction (Oasis HLB cartridges of $60 \mathrm{mg}$, Waters; enrichment factor, 1,000-fold), followed by $\mathrm{GC} / \mathrm{MS}$. In the first campaign, separation and detection were performed on a GC/MS system (Fisons MD 800 mass spectrometer) operated in EI mode at $70 \mathrm{eV}$ and in the second campaign on a GC-ITMS system (Thermo Electron Polaris Q Mass Spectrometer) operated in EI mode at $70 \mathrm{eV}$. The gas chromatographs were equipped with a capillary column HP-5MS $(30 \times 0.25 \mathrm{~mm})$ with $0.25 \mu \mathrm{m}$ film thickness. Caffeine, pentoxifylline, and galaxolide were determined underivatized, whereas the acidic pharmaceuticals, carbamazepine, cyclophosphamide, and ibuprofen, were determined after derivatization with $N$-methyl- $N$-(trimethylsilyl)-trifluoroacetamide (MSTFA, Sigma at $70^{\circ} \mathrm{C}$ for $15 \mathrm{~min}$ ).

For validation, two replicates were performed using river water spiked with $500 \mathrm{ng} / \mathrm{L}$ of each compound. For recoveries over the entire procedure, river water samples were spiked prior to extraction with $10-500 \mathrm{ng} / \mathrm{L}$ of analytes. The calculated amount of PPCPs minus the amount already present before spiking was then divided by the spiked concentration. The recoveries ranged from $55 \%$ to $110 \%$. The results were corrected with the corresponding recovery rates. Calibration curves ranged from 10 to $500 \mathrm{ng} / \mathrm{L}$ (and up to $2,000 \mathrm{ng} / \mathrm{L}$ for caffeine). The response signals showed a linear range from 10 to $500 \mathrm{ng} / \mathrm{L}$ with a correlation coefficient better than 0.9940 . The overall precision was below $15 \%$. The limits of quantification (LOQ) were around $30 \mathrm{ng} / \mathrm{L}$ at the first campaign and around $10 \mathrm{ng} / \mathrm{L}$ at the second campaign. The quantifications were performed using diphenylamine (in the first campaign) and ibuprofen- ${ }^{13} \mathrm{C}_{3}$, caffeine- ${ }^{13} \mathrm{C}_{3}$, and tonalide- $\mathrm{D}_{3}$ (in the second campaign) as an internal standard.

\section{Results and discussions}

The selected compounds are presented in Table 1. The chromatographic separation obtained by diagnostic ions of caffeine, galaxolide, and tonalide, as well as the labeled compounds caffeine- ${ }^{13} \mathrm{C}_{3}$ and tonalide- $\mathrm{D}_{3}$, used as an internal standard, are shown in Fig. 2. For quantification and identification of target compounds, the mass spectra in the full scan mode were used. The concentrations of the target compounds (in nanograms per liter) at sites 1-3 before and after the upgrade of the WWTP in Cluj-Napoca are given in Table 2. The loads (in grams per day) for both sampling campaigns are shown in Fig. 3.

Before the WWTP upgrade, the concentrations of pentoxifylline, a haemorheologic and vasodilator agent, were around $300 \mathrm{ng} / \mathrm{L}$ at sites 1 and 2 (corresponding to a load of $500 \mathrm{~g} /$ day) and below the LOQ at site 3. After the upgrade of the WWTP, the concentrations were below the LOQ at all sites. This behavior is consistent with the working hypothesis that the main source of pentoxifylline is the University Hospital of Cluj-Napoca, Department of Cardiovascular Diseases and that it is efficiently eliminated in the upgraded WWTP with a SRT of approximately 12 days. In a German survey, the concentrations of pentoxifylline were also below the LOQ and only a few nanograms per liter were detected in some effluents of Canadian WWTPs (BLAC 2003; Metcalfe et al. 2003).

Another compound with a similar behavior was cyclophosphamide, an important cytostatic drug used in the chemotherapy of cancer and in the treatment of autoimmune diseases. Thus, residues of cytostatic drugs almost exclusively originate from hospital applications. Cyclophosphamide was not detected above the LOQ (10 ng/L) in any sample during the second campaign. However, in the first campaign before the upgrade, cyclophosphamide was detected at concentrations of 65 and $45 \mathrm{ng} / \mathrm{L}$ at sites 1 and 2 , respectively. At site 3 , the concentrations were $<\mathrm{LOQ}$ presumably due to the confluence of Somesul Mic with Somesul Mare. These concentrations translate to loads of 112 and $89 \mathrm{~g} /$ day at sites 1 and 2, respectively. These concentrations are surprisingly high compared to literature data and one reason could be that the Oncological University Hospital is the sole hospital for cancer treatment in Transylvania and, therefore, the main source for cytostatic drugs. In a German study, cyclophosphamide was determined at maximum concentrations of $20 \mathrm{ng} / \mathrm{L}$ in four out of 16 effluent samples (Ternes 1998). In Switzerland, cyclophosphamide was detected in untreated and treated wastewater at concentrations of 2-11 ng/L and high persistence in WWTPs was suggested (Buerge et al. 2006a). In a German survey, the concentrations of cyclophosphamide in grab samples of wastewaters and surface waters were mostly below the LOQ with few exceptions with levels in wastewaters up to $150 \mathrm{ng} / \mathrm{L}$ and one detected in surface waters at $100 \mathrm{ng} / \mathrm{L}$ (BLAC 2003).

Ibuprofen (an analgesic drug) was frequently detected in effluents and surface waters in Europe due to its high prescription rates and wide usage. In our study, the concentrations at site 1 varied between 85 and $63 \mathrm{ng} / \mathrm{L}$ and at site 2 between 115 and $59 \mathrm{ng} / \mathrm{L}$. In WWTPs, the biological transformation of a compound depends on the age of the activated sludge. Ibuprofen requires an SRT of 2-4 days for a significant $(>90 \%)$ degradation (Ternes et al. 2004; Joss et al. 2005). Assuming a SRT of 2-4 days before the upgrade of the WWTP Cluj-Napoca, a relatively efficient removal of ibuprofen could already be expected. Therefore, an additional increase up to 10-12 days would not show a dramatic improvement of the elimination. The ibuprofen concentrations in the Somes River in both sampling campaigns were probably within the range of daily and weekly variations. The concentrations in the Somes are significantly lower compared to values of 
Table 1 Selected compounds, molecular structures, and quantification ions

\begin{tabular}{|c|c|c|c|}
\hline Compound & Chemical structure & $\begin{array}{l}\text { Chemical formulae } \\
\text { molecular mass }\end{array}$ & Quantification ion \\
\hline Caffeine (1,3,7-trimethyl xanthine) & & $\begin{array}{l}\mathrm{C}_{8} \mathrm{H}_{10} \mathrm{~N}_{4} \mathrm{O}_{2} \\
\mathrm{M}=194\end{array}$ & 194 \\
\hline$(*){ }^{13} \mathrm{C}_{3}$-Caffeine & & $\begin{array}{l}{ }^{13} \mathrm{C}_{3} \mathrm{C}_{5} \mathrm{~N}_{4} \mathrm{O}_{2} \\
\mathrm{M}=197\end{array}$ & 197 \\
\hline $\begin{array}{l}\text { Carbamazepine (5H-dibenz }[b, f] \text { azepine- } 5 \text { - } \\
\text { carboxamide) }\end{array}$ & & $\begin{array}{l}\mathrm{C}_{15} \mathrm{H}_{12} \mathrm{~N}_{2} \mathrm{O} \\
\mathrm{M}=308\end{array}$ & 193 \\
\hline (*) $\mathrm{D}_{10}$-Carbamazepine & & $\begin{array}{l}\mathrm{C}_{15} \mathrm{H}_{2} \mathrm{D}_{10} \mathrm{~N}_{2} \mathrm{O}, \mathrm{TMS} \\
\mathrm{M}=318\end{array}$ & 203 \\
\hline Cyclophosphamide & & $\begin{array}{l}\mathrm{C}_{7} \mathrm{H}_{15} \mathrm{C}_{12} \mathrm{~N}_{2} \mathrm{O}_{2} \mathrm{P} \\
\mathrm{M}=260\end{array}$ & 211 \\
\hline $\begin{array}{l}\text { Galaxolide }(1,3,4,6,7,8 \text {-hexa hydro- } 4,6,6,7,8,8 \text { - } \\
\text { hexamethyl-cyclo penta-(g)-2-benzopyran) } \\
\text { (HHCB) }\end{array}$ & & $\begin{array}{l}\mathrm{C}_{18} \mathrm{H}_{26} \mathrm{O} \\
\mathrm{M}=258\end{array}$ & 243 \\
\hline $\begin{array}{l}\text { Ibuprofen (a-methyl-4(2-methylpropyl)- } \\
\text { benzeneacetic acid) }\end{array}$ & & $\begin{array}{l}\mathrm{C}_{13} \mathrm{H}_{18} \mathrm{O}_{2} \\
\mathrm{M}=278\end{array}$ & 160 \\
\hline$(*){ }^{13} \mathrm{C}_{3}$-Ibuprofen & & $\begin{array}{l}{ }^{13} \mathrm{C}_{3} \mathrm{C}_{10} \mathrm{H}_{18} \mathrm{O}_{2} \\
\mathrm{M}=236\end{array}$ & 162 \\
\hline $\begin{array}{l}\text { Pentoxifylline (3,7-dimethyl-1-(5-oxohexyl) } \\
\text { xanthine) }\end{array}$ & & $\begin{array}{l}\mathrm{C}_{13} \mathrm{H}_{18} \mathrm{~N}_{4} \mathrm{O}_{3} \\
\mathrm{M}=278\end{array}$ & 221 \\
\hline $\begin{array}{l}\text { Tonalide (7-acetyl-1,1,3,4,4,6-hexa } \\
\text { methyltetralin) (AHTN) }\end{array}$ & & $\begin{array}{l}\mathrm{C}_{18} \mathrm{H}_{26} \mathrm{O} \\
\mathrm{M}=258\end{array}$ & 243 \\
\hline (*) $\mathrm{D}_{3}$-Tonalide & & $\begin{array}{l}\mathrm{C}_{18} \mathrm{H}_{23} \mathrm{D}_{3} \mathrm{O} \\
\mathrm{M}=261\end{array}$ & 246 \\
\hline
\end{tabular}

The internal standards are marked with an asterisk

$200 \mathrm{ng} / \mathrm{L}$ as reported for the USA (Kolpin et al. 2002) and UK (Ashton et al. 2004), but comparable to concentrations in Spanish rivers (Gros et al. 2007). In the first campaign the loads at sites 1,2 and 3 were $130,220 \mathrm{~g} / \mathrm{d}$, respectively. In the second campaign the loads at sites 1,2 , and 3 were $108,103,73 \mathrm{~g} / \mathrm{d}$, respectively.
The concentrations and loads of carbamazepine (an antiepileptic and antidepressant) were similar in both sampling campaigns and were relatively constant at the three sampling sites. In the first campaign, the concentrations at sites 1,2 , and 3 were $65 \mathrm{ng} / \mathrm{L}, 72 \mathrm{ng} / \mathrm{L}$, and below the LOQ, respectively, and the LOQ of carbamaze- 
Fig. 2 Chromatograms of the diagnostic ions $m / z$ 194, 197, 243, and 246 for water samples

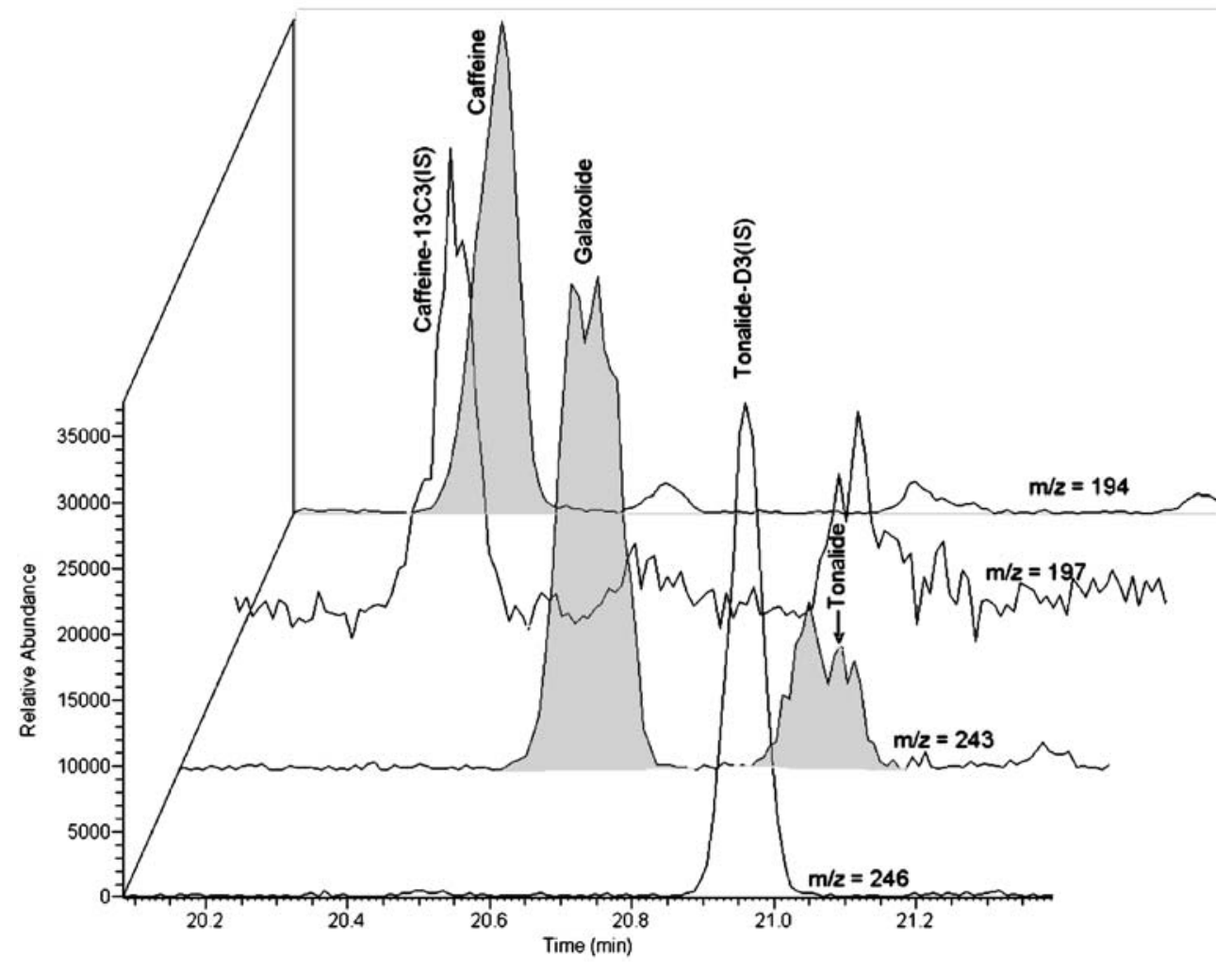

pine was $30 \mathrm{ng} / \mathrm{L}$. The loads at sites 1 and 2 were 113 and $140 \mathrm{~g} /$ day, respectively. In the second campaign (LOQ $<10 \mathrm{ng} / \mathrm{L}$ ), the concentrations at sites 1,2 , and 3 were 45 , 56 , and $35 \mathrm{ng} / \mathrm{L}$, respectively. These concentrations are comparable to other Western European rivers (Gros et al. 2007) or up to one order of magnitude lower compared to rivers with a high share of wastewater effluents with concentrations up to $1,800 \mathrm{ng} / \mathrm{L}$ (BLAC 2003). The corresponding loads at the three sites were 78,96 , and $181 \mathrm{~g} /$ day, respectively. The increase of the load at site 3 is due to the input of the Somesul Mare River where wastewater effluents from relatively important cities (Bistrita, Nasaud, and Beclean) are being discharged. Because carbamazepine is not significantly removed in WWTPs (Jones et al. 2002; Strenn et al. 2004; Wiegel et al. 2004; Joss et al. 2005) it can be a good indicator for evaluating whether surface water is impacted by contamination from municipal sewage effluent or whether contamination associated with sewage effluent can be transported into ground water at ground water recharge sites (Clara et al. 2004; Heberer et al. 2004).

Caffeine has a widespread usage in beverages, food, and pharmaceuticals. Despite the efficient removal in most WWTPs $(>90 \%)$, caffeine is ubiquitously found in rivers and lakes. Caffeine is efficiently eliminated in WWTPs and is, therefore, a suitable indicator for surface water pollution

Table 2 Average concentrations (in nanograms per liter) of the PPCPs before and after the upgrade of the WWTP Cluj-Napoca

\begin{tabular}{|c|c|c|c|c|c|c|c|}
\hline \multirow[t]{2}{*}{ No. } & \multirow[t]{2}{*}{ Compound } & \multicolumn{2}{|c|}{ Site 1 (Cluj-Napoca) } & \multicolumn{2}{|c|}{ Site 2 (Gherla) } & \multicolumn{2}{|c|}{ Site 3 (Dej) } \\
\hline & & Before & After & Before & After & Before & After \\
\hline 1 & Caffeine & 2,772 & 228 & 9,700 & 333 & 428 & 333 \\
\hline 2 & Carbamazepine & 65 & 45 & 72 & 56 & $<\mathrm{LOQ}$ & 38 \\
\hline 3 & Cyclophosphamide & 65 & $<\mathrm{LOQ}$ & 46 & $<\mathrm{LOQ}$ & $<\mathrm{LOQ}$ & $<\mathrm{LOQ}$ \\
\hline 4 & Galaxolide & 300 & 81 & 314 & 155 & 172 & 13 \\
\hline 5 & Ibuprofen & 85 & 63 & 115 & 59 & $<\mathrm{LOQ}$ & 16 \\
\hline 6 & Pentoxifylline & 291 & $<$ LOQ & 299 & $<\mathrm{LOQ}$ & $<\mathrm{LOQ}$ & $<\mathrm{LOQ}$ \\
\hline 7 & Tonalide & 106 & $<\mathrm{LOQ}$ & 101 & $<\mathrm{LOQ}$ & 81 & $<$ LOQ \\
\hline
\end{tabular}



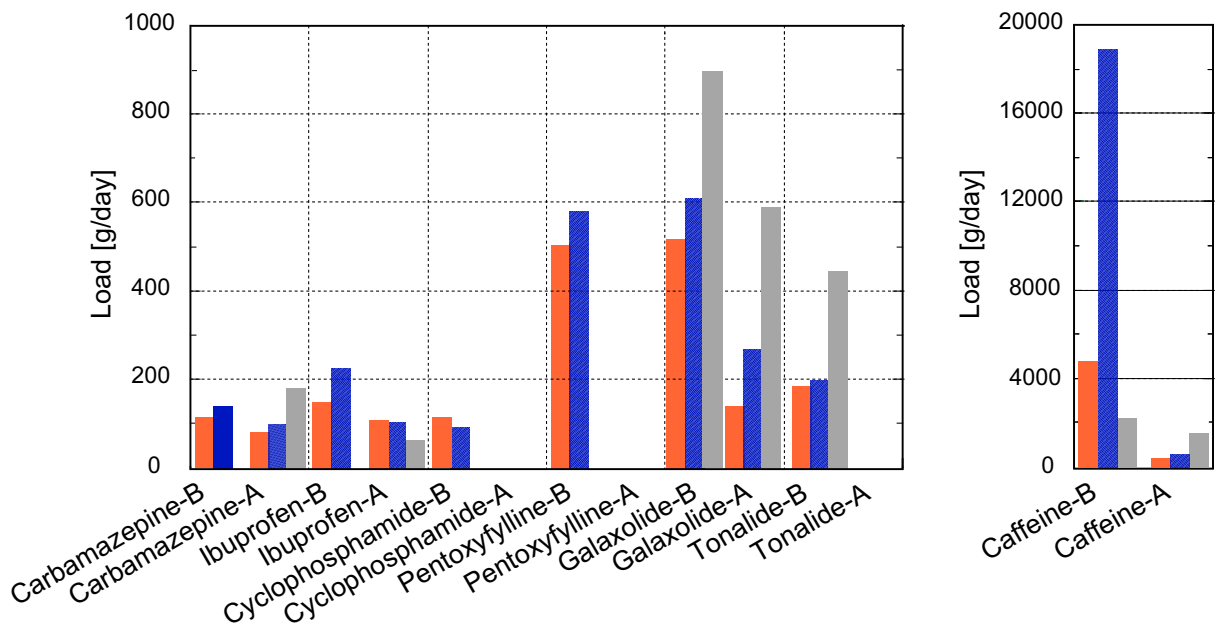

Cluj-Napoca

- Gherla

Dej

Fig. 3 Mass flows of the studied compounds in the Somes River Watershed before $(B)$ and after $(A)$ the upgrade of the WWTP Cluj-Napoca

by untreated municipal wastewater (from combined sewer overflow, direct discharges) (Buerge et al. 2003, 2006b). According to a recent study, caffeine should pose negligible risk for most aquatic vertebrate and invertebrate organisms (Moore et al. 2008). In our first sampling campaign, caffeine was detected at very high concentrations at sites 1 and 2. The average concentrations were up to $2,800 \mathrm{ng} / \mathrm{L}$ at site 1 , over $9,700 \mathrm{ng} / \mathrm{L}$ at site 2 , and $430 \mathrm{ng} / \mathrm{L}$ at site 3 (because of the dilution with the Somesul Mare River with a two times higher water discharge than Somesul Mic River). The corresponding loads were 4,790, 18,850 and $2,229 \mathrm{~g} /$ day, respectively. In the second sampling campaign, the measured concentrations at sites 1,2 , and 3 were 228,332 , and $312 \mathrm{ng} / \mathrm{L}$, respectively. The corresponding loads were 394,576 , and $1,617 \mathrm{~g} /$ day, respectively. Caffeine concentrations and loads found at sites 1 and 2 during the first campaign could not be explained by the discharge of treated wastewater; hence, inputs of untreated wastewater were assumed to be responsible for the comparatively high concentrations. Concentrations of caffeine in untreated wastewater are, in fact, orders of magnitude higher than in treated wastewater (Moldovan 2006), reflecting the improvement of the WWTP ClujNapoca.

Polycyclic musks have been recognized as important contaminants in wastewater effluents and surface waters and have been described to occur as ubiquitous contaminants. They are not readily biodegradable in WWTPs, and an elimination of $50 \%$ is expected to mainly be due to sorption onto sludge (Herren and Berset 2000; Joss et al. 2005). The musk fragrance galaxolide was detected in the first campaign at sites 1 and 2 at concentrations above $300 \mathrm{ng} / \mathrm{L}$ and at site 3 at $170 \mathrm{ng} / \mathrm{L}$. The corresponding loads were above $520 \mathrm{~g}$ /day at sites 1 and 2 and above $890 \mathrm{~g} /$ day at site 3 . In the second campaign, the concentrations were
81,155 , and $113 \mathrm{ng} / \mathrm{L}$ at sites $1-3$, respectively. The corresponding loads were 140, 268, and 586 g/day. The reduction of the load between both campaigns of $73 \%$ (site 1) and $51 \%$ (site 2) may refer to a more efficient elimination through sorption onto sewage sludge after upgrading the WWTP Cluj-Napoca, although the collected grab samples cannot account for temporal variations. Before the WWTP upgrade, the concentrations of tonalide, were around $100 \mathrm{ng} / \mathrm{L}$ (corresponding to a load of 180, 200 $444 \mathrm{~g} / \mathrm{d}$ at sites $1-3$, respectively. After the upgrade, the concentrations were below the LOQ at all sites

One should be cautious in comparing both sampling campaigns because the relative efficiency of the WWTP's removal of PPCP was not evaluated. However, the significant lower concentrations of most compounds after the upgrade of the WWTP Cluj-Napoca allow inferring that the technical measures at the WWTP substantially reduced inputs of contaminants to the receiving river. At Dej, loads of the poorly biodegradable substance carbamazepine increased by a factor of $2-3$ as a result of wastewater discharges into the river. The disproportionate increase in caffeine loads by a factor of 4 below Cluj-Napoca indicates inputs of untreated wastewater from the Somes Mare.

The relative contribution of treated and untreated wastewater in surface water may be assessed by measuring chemical markers. Suitable indicators for wastewater could also help to detect and locate sources of water pollution. Appropriate compounds are, on the one hand, those which are persistent in sewage treatment and mobile in surface waters and groundwater like carbamazepine or compounds that are easily degradable during wastewater treatment and, thus, good indicators for raw sewage. Caffeine is efficiently eliminated in WWTPs and is, therefore, a suitable indicator for surface water pollution by untreated municipal wastewater (from combined sewer overflow, direct discharges) 
(Buerge et al. 2003, 2006b). During the second campaign, the loads at Dej (site 3) of the recalcitrant carbamazepine increased by a factor of 2 compared to site 1 . The concurrent increase of the caffeine load by a factor of nearly 5 refers to a discharge of untreated wastewater into the Somes. Because the increase of the load occurred after the confluence of the Somes Mic and the Somes Mare, this increase must be due to the discharge of untreated wastewater deriving from Bistrita, Nasaud, and Beclean $(115,000$ inhabitants).

\section{Conclusions}

We investigated the environmental exposure of PPCPs before and after an upgrade of the main WWTP discharging into the Somes River. The main conclusions are:

1. The concentrations in the Somes River of the studied PPCPs varied from below $10 \mathrm{ng} / \mathrm{L}$ up to $10 \mu \mathrm{g} / \mathrm{L}$.

2. A substantial decrease of the PPCPs concentrations in the Somes River could be observed due to the upgrade of the municipal WWTP in Cluj-Napoca:

(a) Pentoxifylline and cyclophosphamide were not detected anymore in the Somes River after the WWTP upgrade.

(b) The concentrations and loads of galaxolide decreased significantly at the measuring site 1 after the upgrade.

(c) The contribution of the easily degradable caffeine from the WWTP decreased by one order of magnitude after the upgrade. The load increased after the merger of the Somesul Mare and Somesul Mic can be explained by the discharge of untreated wastewater into Somesul Mare.

(d) The concentrations and loads of carbamazepine remained similar within the expected temporal variations.

3. The relative contribution of treated and untreated wastewater in surface water may be assessed by measuring chemical markers. Recalcitrant pharmaceuticals like carbamazepine are suitable as chemical markers for estimating the relative contribution of wastewater in surface water. The easily degradable caffeine could be a good indicator for untreated wastewaters.

\section{Recommendations and perspectives}

Municipal WWTPs have the potential to make a significant contribution in reducing the loads of pharmaceuticals and other organic contaminants to ambient waters (Joss et al. 2006). Technically and economically feasible options are available for upgrading WWTPs and reducing contaminant load in the effluent. The efficiency of the wastewater treatment in Cluj-Napoca improved considerably after the upgrade of the WWTP. Therefore, it is crucial that, in the Somes Valley Watershed, several WWTPs must be implemented or improved in order to reduce the discharge of contaminants in the Somes from these point sources.

Acknowledgement This work was financed by the Swiss National Science Foundation, the Swiss Agency for Development and Cooperation and the Romanian Ministry for Education and Research within the framework of the Swiss-Romanian cooperation programme on "Environmental Science and Technology in Romania-ESTROM". The reported study was performed in the project PHARMSOMES focusing on environmental exposure of pharmaceuticals in the Somes Valley Watershed in Romania.

\section{References}

Alder AC, Bruchet A, Carballa M, Clara M, Joss A, Löffler D, McArdell CS, Miksch K, Omil F, Tuhkanen T, Ternes TA (2006) Consumption and occurrence. In: Ternes TA, Joss A (eds) Human pharmaceuticals, hormones and fragrances: the challenge of micropollutants in urban water management. IWA, London, UK, pp 15-54

Ashton D, Hilton M, Thomas KV (2004) Investigating the environmental transport of human pharmaceuticals to streams in the United Kingdom. Sci Total Environ 333:167-184

BLAC (2003) Arzneimittel in der Umwelt-Auswertung der Untersuchungsergebnisse. Hamburg, Freie und Hansestadt Hamburg, Behörde für Umwelt und Gesundheit, Umweltuntersuchungen im Auftrag des Bund/Länderauschluss für Chemikaliensicherheit (BLAC)

Buerge IJ, Poiger T, Muller MD, Buser HR (2003) Caffeine, an anthropogenic marker for wastewater contamination of surface waters. Environ Sci Technol 37:691-700

Buerge IJ, Buser HR, Poiger T, Muller MD (2006a) Occurrence and fate of the cytostatic drugs cyclophosphamide and ifosfamide in wastewater and surface waters. Environ Sci Technol 40:7242-7250

Buerge IJ, Poiger T, Muller MD, Buser HR (2006b) Combined sewer overflows to surface waters detected by the anthropogenic marker caffeine. Environ Sci Technol 40:4096-4102

Clara M, Strenn B, Kreuzinger N (2004) Carbamazepine as a possible anthropogenic marker in the aquatic environment: investigations on the behaviour of carbamazepine in wastewater treatment and during groundwater infiltration. Water Res 38:947-954

Daughton CG, Ternes TA (1999) Pharmaceuticals and personal care products in the environment: agents of subtle change? Environ Health Persp 107:907-938

Gros M, Petrovic M, Barcelo D (2007) Wastewater treatment plants as a pathway for aquatic contamination by pharmaceuticals in the Ebro river basin (northeast Spain). Environ Toxicol Chem 26:1553-1562

Halling-Sorensen B, Nielsen SN, Lanzky PF, Ingerslev F, Lutzhoft HCH, Jorgensen SE (1998) Occurrence, fate and effects of pharmaceutical substances in the environment - a review. Chemosphere 36:357-394

Heberer T (2002) Occurrence, fate, and removal of pharmaceutical residues in the aquatic environment: a review of recent research data. Toxicol Lett 131:5-17

Heberer T, Mechlinski A, Fanck B, Knappe A, Massmann G, Pekdeger A, Fritz B (2004) Field studies on the fate and transport of pharmaceutical residues in bank filtration. Ground Water Monit Remediat 24:70-77

Herren D, Berset JD (2000) Nitro musks, nitro musk amino metabolites and polycyclic musks in sewage sludges - quantitative determina- 
tion by HRGC-ion-trap-MS/MS and mass spectral characterization of the amino metabolites. Chemosphere 40:565-574

Jones OAH, Voulvoulis N, Lester JN (2002) Aquatic environmental assessment of the top 25 English prescription pharmaceuticals. Water Res 36:5013-5022

Jones OAH, Voulvoulis N, Lester JN (2005) Human pharmaceuticals in wastewater treatment processes. Crit Rev Environ Sci Technol 35:401-427

Joss A, Keller E, Alder AC, Gobel A, McArdell CS, Ternes T, Siegrist $\mathrm{H}$ (2005) Removal of pharmaceuticals and fragrances in biological wastewater treatment. Water Res 39:3139-3152

Joss A, Carballa M, Kreuzinger N, Siegrist H, Zabczynski S (2006) Wastewater treatment. In: Ternes TA, Joss A (eds) Human pharmaceuticals, hormones and fragrances: the challenge of micropollutants in urban water management. IWA, London, UK, pp 243-292

Khetan SK, Collins TJ (2007) Human pharmaceuticals in the aquatic environment: a challenge to green chemistry. Chem Rev 107:2319-2364

Kolpin DW, Furlong ET, Meyer MT, Thurman EM, Zaugg SD, Barber LB, Buxton HT (2002) Pharmaceuticals, hormones, and other organic wastewater contaminants in US streams, 1999-2000: a national reconnaissance. Environ Sci Technol 36:1202-1211

Lishman L, Smyth SA, Sarafin K, Kleywegt S, Toito J, Peart T, Lee B, Servos M, Beland M, Seto P (2006) Occurrence and reductions of pharmaceuticals and personal care products and estrogens by municipal wastewater treatment plants in Ontario, Canada. Sci Total Environ 367:544-558
Metcalfe CD, Koenig BG, Bennie DT, Servos M, Ternes TA, Hirsch R (2003) Occurrence of neutral and acidic drugs in the effluents of Canadian sewage treatment plants. Environ Toxicol Chem 22:2872-2880

Moldovan Z (2006) Occurrences of pharmaceutical and personal care products as micropollutants in rivers from Romania. Chemosphere 64:1808-1817

Moldovan Z, Schmutzer G, Tusa F, Calin R, Alder AC (2007) An overview of pharmaceuticals and personal care products contamination along the river Somes watershed, Romania. J Environ Monit 9:986-993

Moore MT, Greenway SL, Farris JL, Guerra B (2008) Assessing caffeine as an emerging environmental concern using conventional approaches. Arch Environ Contam Toxicol 54:31-35

Strenn B, Clara M, Gans O, Kreuzinger N (2004) Carbamazepine, diclofenac, ibuprofen and bezafibrate-investigations on the behaviour of selected pharmaceuticals during wastewater treatment. Water Sci Technol 50:269-276

Ternes TA (1998) Occurrence of drugs in German sewage treatment plants and rivers. Water Res 32:3245-3260

Ternes TA, Joss A, Siegrist H (2004) Scrutinizing pharmaceuticals and personal care products in wastewater treatment. Environ Sci Technol 38:392A-399A

Wiegel S, Aulinger A, Brockmeyer R, Harms H, Loffler J, Reincke H, Schmidt R, Stachel B, von Tumpling W, Wanke A (2004) Pharmaceuticals in the river Elbe and its tributaries. Chemosphere 57:106-127 